Ковальська Наталя Михайлівна кандидат педагогічних наук, доцент, доцент кафедри державного управління i місцевого самоврядування, Херсонський національний технічний університет, Бериславське Шосе, 24, м. Херсон, 73008, тел.: (0552) 32-69-09, e-mail: kovalsknm@ukr.net, https://orcid.org/0000-0002-5758-8373

\title{
РИЗИКИ ВИБОРЧИХ ТЕХНОЛОГІЙ У СОЦІАЛЬНОМУ ВИМІРІ
}

Анотація. У статті досліджено ризики соціальних трансформацій, що зумовлені порушеннями й неправовими колізіями у виборчому процесі через нелегітимні виборчі технології. 3'ясовано, що в іншому разі вдосконалення виборчих технологій в Україні безпосередньо пов'язане з розвитком демократії. Визначено такі ризики, як цілеспрямоване досягнення певною політичною силою своїх прихованих прагнень, не декларованих у виборчій програмі, що виявляють інтереси окремих осіб - як представників цієї сили, так і iї спонсорів; психологічний вплив - маніпуляція, що використовує традиційну невдоволеність електорату чинною владою, а тому часто базується на викривленій чи неправдивій інформації; цілеспрямоване відволікання людей від реалій життя, що призводить до некритичного ставлення до будь-якої інформації, що спрямована проти чинної влади; неаргументоване «навішування ярликів» і «шельмування» певних осіб - правозахисників, опозиціонерів, що ставить фальшування на перше місце в пріоритетах людської свідомості; замовчування правдивої інформації, що викличе супротив певної частини електорату (наприклад, щодо минулої війни чи щодо нинішньої легальної діяльності російських ультраправих націоналістів); викидання в медіа-простір неправдивих чуток (фейків) задля формування сумніву щодо вже вибраної подумки кандидатури; залякування через навіювання почуття страху або й навіть нейролінгвістичне програмування, що становить ризик для психічного здоров'я людей, які потрапляють у депресивний стан; використання авторитету різноманітних рейтингів, екзитполів, даних опитування громадської думки щодо ставлення до кандидатів або проблем і бажань населення, що часто відбувається на замовлення - тенденційно (результати таких досліджень перекручуються або представляються вибірково - як вигідно політичній силі, яка замовила цю інформацію).

Зроблено висновок, що впровадження «чистих» виборчих технологій, які формують політичну культуру громадян, може відбутися за умов доступу їх до медіа-засобів, ознайомлення зі світовим досвідом громадського життя, посилення правової відповідальності за неправові дії в цій сфері, посилення громадського контролю за виборчим процесом й урахування національних особливостей країни 
чи регіону, якщо це не йтиме врозріз із загальною державною політикою та цивілізаційними основами світового співжиття.

Ключові слова: виборчі технології, виборчий процес, маніпуляція, психологічне навіювання, соціальні ризики, претенденти, електорат.

Kovalska Natalia Mykhailivna Candidate of Pedagogical Sciences, Associate Professor, Associate Professor of Department of Public Administration and Local SelfGovernment, Kherson National Technical University, Beryslav Highway, 24, Kherson, 73008, tel.: (0552) 32-69-09, e-mail: kovalsknm@ukr.net, https://orcid.org/0000-00025758-8373

\section{RISKS OF ELECTION TECHNOLOGIES IN THE SOCIAL DIMENSION}

Abstract. The article examines the risks of social transformations caused by violations and illegal conflicts in the electoral process due to illegitimate electoral technologies. It was found that otherwise the improvement of election technologies in Ukraine is directly related to the development of democracy. Risks are identified, such as the purposeful achievement by a certain political force of its hidden aspirations, not declared in the election program, which reveal the interests of individuals - both representatives of this force and its sponsors; psychological influence - manipulation that uses the traditional dissatisfaction of the electorate with the current government, and therefore is often based on distorted or false information; purposeful distraction of people from the realities of life, which leads to uncritical attitude to any information directed against the current government; unsubstantiated «labeling» and «slandering» of certain persons - human rights activists, oppositionists, which puts falsification in the first place in the priorities of human consciousness; withholding truthful information that would provoke opposition from a certain part of the electorate (for example, about the past war or about the current legal activities of Russian far-right nationalists); throwing false rumors (fakes) into the media space in order to form doubts about the already chosen opinion of the candidate; intimidation due to fear or even neurolinguistic programming, which poses a risk to the mental health of people who become depressed; the use of the authority of various ratings, exit polls, public opinion polls on candidates' attitudes or problems and desires of the population, which often happens to order - tendentious (the results of such surveys are distorted or presented selectively - as beneficial to the political force that ordered this information).

It is concluded that the introduction of «clean» electoral technologies that shape the political culture of citizens can take place under conditions of their access to media, acquaintance with the world experience of public life, strengthening legal responsibility for illegal actions in this area, strengthening public control over electoral process and taking into account the national characteristics of the country or region, if it does not conflict with the general state policy and the civilization foundations of world coexistence. 
Keywords: election technologies, election process, manipulation, psychological suggestion, social risks, contenders, electorate.

Постановка проблеми. Упродовж 30 років офіційної незалежності Української держави численні вибори до Верховної Ради, місцевих рад, а також на посади Президента та муніципальних керівників виявили чимало порушень виборчого законодавства, зокрема через використання «чорних» / «брудних» політичних технологій, які негативно впливають не лише на ефективність самих виборів, але й на формування цивілізованої виборчої культури громадян України. Також такі технології заважають прагненню українців до Європейського Союзу, адже призводять до свавілля влади, зокрема повного використання нею адміністративного ресурсу, сприяли розвитку корупції в напрямку прихованого впливу капіталу на виборчий процес. Ці моменти складають небезпеку для соціальної стабільності в державі, тобто становлять ризик громадського протесту й навіть заворушень, що й відбулося під час виборів 2004 року. Зрештою ці негативні процеси загалом гальмують розвиток країни.

Аналіз останніх досліджень і публікацій. Відповідно до цієї актуальної проблеми науковці - політологи, юристи, державники та психологи досліджують виборчі процеси й надають практичні рекомендації державній владі. Ще в 90-ті роки - у період утвердження виборчих традицій в Україні - чимало досліджень було присвячено сутності виборчих технологій. Так, у монографії А. Пойченка [1] розглядаються загалом політичні технології, серед яких виборчі виділяються як основні. Надалі Д. Видрін [2] досліджує історію застосування таких технологій, їх екзистенційний вимір, С. Куценко [3] докладно характеризує цю категорію за сутністю й диференціацією, виокремлюючи іiі в колі інших технологій за соціально-економічними галузями. Надалі вчені вже не констатують актуальність цього терміна, а користуються ним як готовим i відомим інструментом наукового аналізу. Наприклад, А. Нальотов [4] одним із чинників виборчих технологій визначає їхній вплив на масову свідомість, Ю. Шведа та І. Лесечко [5] аналізують сучасну виборчу практику, визначаючи деструктивні виборчі технології, М. Ільницький [6] розглядає такі технології 3 правового боку, а Є. Блінов [7] пропонує протидію використанню нелегітимних політичних технологій, базуючись на зарубіжному й вітчизняному досвіді.

Мета статті. Незважаючи на численні дослідження виборчих технологій недостатньо дослідженими залишається аспект їхніх потенційних ризиків щодо стабільності в суспільстві. Тому метою цієї статті визначаємо виявлення ризиків виборчих технологій у соціальному вимірі, що наявні в разі їх нелегітимності невідповідності законодавству.

Виклад основного матеріалу. Під час виборчого процесу спостерігається взаємодія різних соціальних прошарків суспільства через різноманітні діяльнісні чинники - духовні, економічні, політичні, психологічні, правові, коли виявляються протилежні погляди виборців. Наприклад, 2004 року на виборчих 
ділянках часто траплялися суперечки навіть між членами одного подружжя, що репрезентували повністю протилежні оцінні характеристики претендентів на пост Президента України. Тобто протиборство цих претендентів повною мірою передалося на протиборство виборців. 3 іншого боку, 3 підвищенням рівня демократичності суспільства формується цивілізована політична культура населення країни. Таким чином, удосконалення виборчих технологій в Україні безпосередньо пов'язане з розвитком демократії. I навпаки - ризики соціальних трансформацій зумовлені порушеннями й неправовими колізіями у виборчому процесі. У статті робимо спробу визначити такі ризики.

Є. Куценко визначає виборчі технології як сукупність «засобів і алгоритмів цілеспрямованого політико-психологічного впливу на електоральні настрої та поведінку» 3 метою досягнення певною політичною силою під час виборчої кампанії власних цілей [3, с. 387]. Відразу зауважимо, що ці цілі не обов'язково зазначені / декларовані у програмі певної партії - це можуть бути приховані (завуальовані) прагнення, пов'язані з інтересами окремих осіб - як представників цієї сили, так і спонсорів виборчої кампанії, які таким чином реалізують і свої довгострокові плани, пов’язані з ринком. Тобто численні преференції для певних окремих осіб у межах державної політики можна назвати прихованим олігархічним впливом на неї. Теза «психологічний вплив на електоральні настрої та поведінку» також має під собою прихований ризик у соціальному вимірі, адже відкрито оголошує про маніпулювання масовою свідомістю, що всі розуміють, але все одно підкоряються такому впливові; тобто така людина ніби свідомо згоджується зі своєю підвладною роллю в цьому процесі.

Така підвладність електорату / народу / громадян спостерігається ще 3 античних часів, тобто має кількатисячолітню історію. Якщо випустити історію псевдодемократичних режимів, де взагалі вибори перетворено на фікцію (наприклад, радянських, де були наявні всі атрибути - передвиборча кампанія, виборчі ділянки, бюлетені, звіти тощо, але насправді вибиралися вже готові й ухвалені зверху депутати), то маємо чимало прикладів маніпулювання тією масовою свідомістю. Це явище має насамперед психологічний характер, а тому серед підходів до розгляду політичних технологій (інструментальний, комунікативний, стратегічний, лідерський тощо [3, с. 393-394]) вирізняємо саме психологічний, який i передбачає вивчення суспільних пріоритетів, думок, настроїв, а тоді вже - відповідний психологічний вплив (маніпуляцію), що полягає в доставлянні потрібної в таких умовах інформації електорату - через відкриті виступи представників певної політичної сили, їхні дебати з опонентами, телевізійні програми, газетні матеріали тощо.

Звісно, учені пов'язують маніпуляцію із соціальними ризиками. Так, Д. Видрін у монографічному дослідженні навіть вводить опозиційний термін «антитехнології», уже цим передбачаючи ризикованість політичного впливу i протиставляючи довготривалий процес формування політичної свідомості / культури громадян короткостроковим результатам, які здобуваються на грунті 
незадоволеності певних соціальних прошарків, що завжди існує [2, с. 263]. Повністю згоджуємося 3 дослідником, адже навіть незначне соціальне розшарування в суспільстві зумовлює таку незадоволеність. I навіть більшою мірою - ті ж пенсіонери завжди становлять такий невдоволений прошарок, бо ж до певних соціальних проблем у них додаються ще й проблеми зі здоров'ям i комунікацією.

Відзначений нами негативний аспект виборчих технологій підтверджується також застосуванням щодо маніпулятивної системи терміна «ірраціональна» на відміну від «раціональної», що передбачає конкретний безпосередній вплив - або спрямований на реалізацію розумних інтересів електорату, або протилежний таким інтересам [3, с. 396]. Остання ситуація стосується соціально-політичних колізій - тиранічного правління, проведення виборів у місцях позбавлення волі чи в інших обставинах безпосередньої (матеріальної, моральної чи й фізичної) залежності електорату.

А. Нальотов для характеристики маніпулювання масовою свідомістю під час виборчого процесу залучає думки видатних філософів і психологів, за якими це явище здійснюється таємно, через що становить загрозу об'єктам впливу, певною мірою фальшиво й ірраціонально, через що відволікає людей від реалій життя, міфологічно, через що тези пропагандистів сприймаються некритично, причому такі міфи зрештою наповнюють усе суспільство - не лише маси, але й управлінську еліту. Але все це відбувається цілеспрямовано, що призводить зрештою до досягнення потрібного маніпулятору результату [4, с. 126-128].

Також маніпуляція передбачає ризик соціального травмування, адже інформація, подана у формі об’єктивної (насправді міфологічна), тисне на «больові точки суспільної свідомості», що викликає негативні реакції людей об'єктів політичного спливу, які стають роздратованими. А оскільки це переважно люди похилого віку, то настає небезпека психічного розладу чи й навіть смерті через інфаркт, інсульт тощо. Якщо проаналізувати будь-яку бесіду між представниками цього прошарку населення, то побачимо домінування негативних думок, характеристик влади, що в результаті призводить до формування депресивного стану серед цілого покоління громадян. Ці громадяни вже готові на виборах віддати свій голос не за когось нового, а цілеспрямовано проти чинної влади.

Серед методів маніпулювання масовою свідомістю А. Нальотов зокрема визначає «підтасування фактів, замовчування небажаної інформації, поширення наклепів», а також напівправду (подається вигідна інтерпретація факту), неаргументоване «навішування ярликів» («шовіністи», «фашисти», «хунта», «бандерівці», «імперіалісти» тощо), оголошення вибіркових рейтингів, опитувань (iз тенденційним підходом до їх результатів) [4, с. 130]. Зауважимо, що всі ці методи $є$ шкідливими для формування цивілізованої політичної (виборчої) культури, адже ставлять фальшування на перше місце в пріоритетах людської свідомості. Так, ще від часів тоталітаризму у відповідних суспільствах існує й 
«шельмування» певних осіб - правозахисників, опозиціонерів, і замовчується інформація, що суперечить проголошеній державній концепції (наприклад, щодо викриття економічних махінацій, здійснюваних відомими олігархами чи й самим президентом, або щодо псевдогероїв минулої війни, «подвиги» яких були пов’язані із загибеллю великої кількості співгромадян), і даються «ярлики» без відповідної аргументації та історичної ретроспективи.

Такий аналіз призвів би до відновлення соціально-історичної справедливості. Наприклад, маркування патріотичних сил України терміном «націоналісти» розпочалося разом із постанням влади більшовиків (аналогічно «басмачі» в туркестанській частині підвладної їм території) - iз конкретизаційними назвами «петлюрівці», «бандерівці», «есесівці дивізії “Галичина"» тощо. Це був прийом маніпуляції, що призвів до утвердження цих термінів у свідомості кількох поколінь як позначень саме українців, які виявляють хоч якоюсь мірою любов до української культури. Проте всюди замовчуються факт наявності в Росії під час війни набагато більшої кількості тих «есесівців» і факт нинішньої легальної діяльності російських ультраправих націоналістів, які активно діють і на територіях, захоплених в Україні. У такому разі націоналісти перетворюються вже на шовіністів. Отже, відбувається маркування українців термінами, які повною мірою стосуються росіян. Відмінність полягає ще й у тому, що перших не підтримує ні держава, ні громадська думка, а другі є ледь не героями у своїй «федеративній» державі.

Зрозуміло, що ту частину українського електорату, яка $є$ прибічниками російської політики, переконати в такій невідповідності антиукраїнських ідеологічних гасел немає сенсу взагалі (за психологічною наукою, включається механізм блокування - «а я нічого не чую»), як i проукраїнську частину примусити сумніватися в ідеї незалежності (задіяний той самий психічний механізм), але більша частина народу України - маргінали, які або вірять у будьяку неправдиву інформацію, або не вірять нікому. Хоча й сумнівно, що останні не мають певних політичних пріоритетів. В умовах такого протистояння традиційні «ліві» сили, які автоматично є антиукраїнськими, насправді є «правими» - але 3 боку вже Росії, а тому звичайними ворогами української державності. Що ж стосується маргіналів, то це і є головний об'єкт роботи / впливу політичної системи країни, головний клопіт ідеологів.

Також до активно вживаних брудних технологій А. Рубан відносить дублювання кандидатів (висування в одному окрузі осіб з однаковим прізвищем) iз метою розпорошення голосів за опонента, підкуп виборців - зокрема відбирання в них бюлетенів, заміна чи псування бюлетенів [8, с. 108], до чого ще можна додати найбільш сучасний метод фейкування інформації, тобто викидання в медіа-простір неправдивих чуток, що робиться найчастіше за день-два до виборів - як грунт для сумніву щодо вже вибраної подумки кандидатури. Ю. Шведа та I. Лесечко як один із прийомів ризикованих виборчих технологій відзначають залякування, що полягає не в погрозах, а в навіюванні почуття 
страху. Прикладом є практика 2 туру президентських виборів 1999 року, коли прибічники Л. Кучми залякували електорат злодіяннями комуністів, аби ті не голосували за П. Симоненка [5, с. 118]. Так само під час обрання В. Зеленського було акцентовано на темі війни, адже претендент обіцяв у першу чергу іiі закінчити - в іншому разі буде продовжуватися кровопролиття й будуть нові жертви.

Серед таких нелегітимних технологій учені відзначають навіть засоби нейролінгвістичного програмування, що хоча й не призводять до значних результатів, але, на нашу думку, містять значний ризик, пов'язаний із психічним здоров'ям людей, які дивляться певний відеоролик. Це, наприклад, так званий 25й кадр, що містить негативну інформацію. I взагалі найефективнішим джерелом поширення такої маніпулятивної інформації $є$ медіа-засоби, що, як відомо, в Україні не бувають вільними й незалежними. Це також становить ризик, і вже міжнародного масштабу, адже за таких умов нам буде нереально потрапити в коло країн-членів Свропейського Союзу. Ю. Шведа та І. Лесечко зазначають навіть про «падіння авторитету всієї соціологічної науки» через маніпулювання результатами соціологічних досліджень, адже вона «з інструменту дослідження громадської думки перетворилася в засіб політичної боротьби». У такому разі використовують i підраховують лише потрібні замовнику відповіді, які й публікуються [5, с. 119]. При цьому визначальну роль відіграє маркування таких досліджень як «наукових», а тому реальних й аргументованих. Ще більш ефективно в такому разі залучити авторитетного науковця-академіка, повага до регалій якого ще викликає довіру населення, зокрема людей похилого віку.

При цьому А. Нальотов слушно зазначає, що політичне маніпулювання потрібне не лише для досягнення результатів під час виборчої кампанії, але й для збереження чинної влади, коли соціальні міфи протистоять реаліям, які відбуваються на очах підвладних людей. Зрештою це явище переважно наповнює виборчі технології як стратегічний інструмент «заохочення та утримання уваги, а також формування позитивного іміджу претендента на владу» [4, с. 129]. Також учений аналізує такий засіб психологічного навіювання, як залучення до пропагандистського впливу теми смерті [4, с. 132]. Так, темою загиблих героїв минулої війни був переповнений відповідний дискурс, що й до цього часу (через 75 років!) залишається актуальним і навіть дійовим для «лівих» (тобто «правих» - див. вище) сил. 3 іншого боку, герої сьогоденної війни й по своїй смерті сприяють утвердженню незалежної України, адже, по-перше, $є$ чинником переконання «маргіналів» і навіть деяких внутрішніх ворогів у справедливості української військової сили, а по-друге - наочною агітацією української національної системи цінностей, яка передбачає і своїх героїв - тобто не так минулої війни («радянської»), як сьогоднішньої (української). Отже, ризик від використання такого прийому мінімальний.

Є. Блінов описує таку нелегітимну технологію, як «війна соціологічних рейтингів», коли саме ті особи, які сумніваються, вагаються, $є$ підвладними 
інформації про статус претендента, громадську думку щодо нього, визначену в соціологічному опитуванні, певному рейтингу, екзитполі тощо. При цьому ризик соціального збурення існує за умови прихованості, непрозорості таких технологій. Так, під час виборів 2004 року відбувся скандал через підтасовування даних екзитполу, що також увійшов до причин наступного Майдану. Аналізується також технологія «ухваленого - відкладеного рішення», коли попередня влада не виконує непопулярне рішення на свою користь, але виконує його, вже склавши повноваження, щоб наступна влада потрапила у складну ситуацію [7, с. 76-78].

Як бачимо, більшість ризиків, що виявляються під час виборчої кампанії, безпосередньо пов'язані з низькою політичною культурою українського народу. Так, один 3 аспектів, які залучаються у виборчих технологіях, передбачає врахування інформації про особливості країни чи регіону, де провадиться політична агітація, тобто які погляди переважають у місцевому соціумі, які проблеми там хвилюють людей; стратегічний чинник передбачає створення відповідної програми для досягнення результату політичного впливу; тактичний чинник включає інструменти для такого досягнення - сукупність засобів i методів [1, с. 47-54]. Ризик міститься в першому з наведених чинників, адже, поперше, маніпулювання відбувається 3 використанням «болючих» проблем місцевого населення, які б вони не були, - навіть певною мірою антидержавних; по-друге, самі політтехнологи таким чином не $є$ провідниками державницьких ідей, а просто маніпуляторами масової свідомості. У свою чергу така поведінка може призвести до порушень законодавства, зокрема виборчого.

Також існує дискусія щодо розмежування передвиборчих і виборчих технологій з акцентом на останніх, які й відповідають виборчому процесу [3, с. 397], яка, на нашу думку, дещо звужена в темпоральному вимірі. Є. Куценко слушно назвав їх «електоральними», зважаючи на головний об'єкт психологічного впливу. Проте вважаємо, що цей процес не закінчується 3 перемогою певних сил, адже невдоволені залишаються - спочатку опозиція, а надалі й колишні прибічники, які голосували за переможця. Така психологія пересічного громадянина, який не має високої політичної культури. Тому думаємо, що виборчий процес у своєму повному значенні актуальний завжди, поки така культура не виробилася. У часовому ж вимірі термін «виборчий процес», звісно, стосується саме виборчого періоду.

Тобто електорат у своєму примітивному вигляді - як суто механізм виборів влади - використовується в інтересах політичних сил, що представлені на таких виборах. В історичній ретроспективі цей механізм описує М. Ільницький, аналізуючи правовий аспект виборчих технологій. На першому етапі - у газетну епоху - діяли наймані агітатори, волонтери, активно використовувалися плакати та партійна преса, об’єктом впливу була цільова аудиторія; на другому телевізійному - діяли спеціальні комітети окремих партій, що впливали на всі прошарки суспільства; на третьому - цифровому - діють нові телекомунікаційні 
технології, що мають впливати на електорат. Вони мають різні ознаки інноваційність, витратність, прогнозованість, легальність, етичність, спосіб дії, ефективність, за якими й характеризуються науковцями [6, с. 22].

Аналізуючи вже українські вибори в ретроспективі, Ю. Шведа та І. Лесечко акцентують на проблемі використання адміністративного ресурсу й відзначають, що найбільш «чистими» в цьому вимірі були перші двоє виборів до Верховної Ради, а з 2002 року відбувався вже «прямий адміністративний тиск» на політичну опозицію із залученням навіть силових структур. Поступово такий вплив посилювався, i вибори президента В. Януковича 2004 року стали «найбруднішими» - уся владна вертикаль працювала на його перемогу, адміністративний ресурс поступово збільшувався, цим ресурсом повністю було охоплено Схід і Південь України, активно використовувались як силові структури, так і кримінальні, медіа працювали виключно на цю кандидатуру [5, c. 117]. Це зрештою призвело до масових заворушень і Майдану, коли свідомі виборці таким чином виявили свій протест проти свавілля влади.

Зауважимо з приводу цього, що перші вибори попри активну участь нових політичних сил усе одно контролювалися певною мірою колишніми радянськими структурами, й навряд чи у країні, народ якої так прагнув незалежності й ненавидів колишню владу (наприклад, у Румунії, де розстріляли навіть Президента), вибрали б колишнього секретаря ЦК КПРС з ідеології Л. Кравчука, а депутатом став колишній перший секретар ЦК КПУ В. Івашко. Такі люди, звісно, були б відсторонені взагалі від політичної діяльності. Те ж стосується й адміністративних осіб, які підтримували В. Януковича (зокрема всієї системи MBC) і за логікою мали бути звільнені відразу після «Помаранчевої революції». Тобто як соціальний ризик такої системи відзначаємо некараність за порушення виборчого законодавства.

Отже, виборчі технології традиційно поділяються на «білі», «чорні» й «сірі» за їх відповідністю законодавству: перші передбачають використання наочної агітації, зустрічі з виборцями, дебати претендентів, другі - порушують чинне законодавство й передбачають прийоми, засновані на обмані електорату; треті не порушують законодавство, але протистоять неписаним правилам моралі скажімо, зустрічні виступи з компроматом на супротивника. Означені негативні технології, що містять відповідні соціальні ризики, називають ще антитехнологіями чи нелегальними технологіями. Так, С. Блінов пов’язує їх із порушеннями закону та моральних настанов українського соціуму та називає найсерйознішими викликами для України, адже вони орієнтовані на маніпулювання та не відповідають європейським принципам [7, с. 75].

На відміну від «брудних» виборчих технологій, що передбачають обманні діï, існують і «чисті», критерії яких позначає А. Нальотов - відкритість, прозорість, зрозумілість, конструктивність, послідовність, демократичність i державність [6, с. 134]. Серед цих критеріїв відзначаємо перший і останній, де відкритість пов'язана 3 прозорістю та демократичністю, а державність полягає в 
дотриманні головного гасла - «розквіт України». Саме цей критерій і визначає проукраїнські сили та антиукраїнські, адже останні, впроваджуючи це гасло у своїх програмах, мають на увазі розквіт нової імперії, частиною якої були б українські землі.

Серед заходів сприяння переходу від «брудних» виборчих технологій до «чистих», визначених А. Нальотовим, можна виділити відкриття доступу громадян до світового досвіду громадського життя, ознайомлення 3 даними про збитки від «брудних» технологій, відкрите впровадження «чистих» технологій у реалізації програми політичної сили - переможця виборів [6, с. 136]. С. Блінов пропонує заходи для регулювання сфери виборчих / політичних технологій, серед яких відзначаємо посилення правової відповідальності за неправові дії, посилення громадського контролю за виборчим процесом, урахування зарубіжного досвіду в організації виборчого процесу [7, с. 81]. А. Рубан пов'язує ефективність організації та проведення виборів із такими чинниками, як наявність команди фахівців, достатність матеріальних ресурсів, доступність до медіа-засобів, підтримка відомих людей, наявність харизми в кандидатів [8, с. 108]. До цього можна додати потребу врахування національних особливостей країни чи регіону, що враховуватиме історичні й етнічні традиції населення, їх конфесійні й мовні пріоритети. Це взагалі-то й робиться, але у практиці застосування «брудних» виборчих технологій, коли місцеві пріоритети протиставляються загальнодержавним.

Якщо взяти за основу зауваження А. Рубан щодо того, що визначення виборчих технологій як науково обгрунтованих, чесних і професійних підходить розвинутому демократичному суспільству «з усталеними правилами політичної боротьби», а в нашому ж суспільстві більшість населення лише таким чином виявляють свою участь у політиці, тобто репрезентують свою політичну позицію [8, с. 106], то можна висловити бажання щодо більшої політичної активізації українського народу - насамперед через реалізацію муніципальних інтересів, яка призведе й до поступового формування політичної / виборчої культури.

Висновки. Серед виборчих технологій, які застосовуються в Україні, визначаються нелегітимні, що не лише порушують законодавство, але й становлять ризик соціального протистояння електорату з чинною владою.

Ризик 1. Цілеспрямований політико-психологічний вплив на електорат задля досягнення певною політичною силою під час виборчої кампанії власних цілей не завжди відбувається відповідно до положень, декларованих у програмі цієї сили. Це можуть бути або приховані прагнення, пов'язані з інтересами окремих осіб як представників цієї сили, так і спонсорів виборчої кампанії, зокрема й олігархів.

Ризик 2. Психологічний підхід до розгляду політичних технологій передбачає поряд із вивченням суспільних пріоритетів і настроїв відповідний психологічний вплив - маніпуляцію, що полягає в доставлянні потрібної в таких умовах інформації електорату. Така інформація часто $\epsilon$ викривленою чи неправдивою та базується на невдоволенні електорату чинною владою. 
Ризик 3. Використана неправдива чи перекручена інформація становить загрозу об'єктам впливу, адже відволікає людей від реалій життя. Головна небезпека цього явища - цілеспрямованість, що призводить зрештою до досягнення потрібного маніпулятору результату - безпосередньо через формування в людей постійного роздратування та некритичного ставлення до будь-якої інформації, що спрямована проти чинної влади.

Ризик 4. Актуальним у протистоянні 3 неоімперськими силами $є$ такий прийом «брудних» технологій, як неаргументоване «навішування ярликів» («шовіністи», «фашисти», «бандерівці» тощо), зокрема й «шельмування» певних осіб - правозахисників, опозиціонерів, що $\epsilon$ шкідливим для формування цивілізованої політичної / виборчої культури, адже ставить фальшування на перше місце в пріоритетах людської свідомості. 3 іншого боку, замовчується правдива інформація, що викличе супротив певної частини електорату (наприклад, щодо псевдогероїв минулої війни, «подвиги» яких були пов'язані із загибеллю великої кількості співгромадян, або щодо наявності під час минулої війни великої кількості російських «есесівських» частин, а також щодо нинішньої легальної діяльності російських ультраправих націоналістів).

Ризик 5. Такі методи, як викидання в медіа-простір неправдивих чуток (фейків), що робиться найчастіше за день-два до виборів - як грунт для сумніву щодо вже вибраної подумки кандидатури, або залякування - навіювання почуття страху (теми смерті, війни), або й навіть нейролінгвістичне програмування хоча й не призводять до значних результатів, але містять значний ризик, пов'язаний із психічним здоров'ям людей, які потрапляють під тиск депресивного настрою. Особливо це стосується людей похилого віку.

Ризик 6. Залучення різноманітних рейтингів, екзитполів, даних опитування громадської думки щодо ставлення до кандидатів або проблем i бажань населення часто відбувається тенденційно, коли результати таких досліджень перекручуються або представляються вибірково - як вигідно політичній силі, яка замовила цю інформацію. Цей ризик також зумовлений відсутністю в Україні насправді вільних медіа, що безпосередньо загрожує розвитку демократії нарівні 3 корупцією.

Зазначені ризики безпосередньо пов'язані з низькою політичною культурою українського народу, в навпаки - скільки вони будуть актуальні, стільки цей електорат буде аморфним. Тому для впровадження «чистих» виборчих технологій пропонуються певні конкретні шляхи: відкрите впровадження «чистих» технологій у реалізації програми політичної сили - переможця виборів, ознайомлення громадян зі світовим досвідом громадського життя, ознайомлення 3 даними про збитки від «брудних» технологій, посилення правової відповідальності за неправові дії, посилення громадського контролю за виборчим процесом, урахування національних особливостей країни чи регіону, що враховуватиме історичні й етнічні традиції населення, їх конфесійні й мовні пріоритети. І головне - усі ці шляхи не мають іти супротив загальної державної 
політики та цивілізаційних основ світового співжиття.

\section{Лimepamypa:}

1. Пойченко А. Політика: теорія і технології діяльності. - Київ, 1996. 163 с.

2. Видрін Д. Політика: історія, технологія, екзистенція. - Київ : Либідь, 2001. - 432 с.

3. Куценко Є. «Виборчі технології» як наукова категорія: сутність і класифікації. Наукові записки І Інституту політичних і етнонаціональних досліджень ім. І.Ф. Кураса НАН України. 2013. - Вип. 1 (63). - С. 387-403.

4. Нальотов А. Виборчі технології як чинник впливу на масову свідомість. Політичний менеджмент. - 2007. - № 5. - С. 126-137.

5. Шведа Ю., Лесечко І. Деструктивні виборчі технології в українській виборчій практиці. Науковий вісник Ужгородського університету. Серія: Політологія, Соціологія, Філософія. 2010. Вип. 15. С. 117-120.

6. Ільницький М. Виборчі технології як форма правореалізації. Національний юридичний журнал: теорія і практика. 2018. червень. С. 21-24.

7. Блінов С. Протидія використанню нелегітимних політичних технологій: український і міжнародний досвід. Державне управління та місцеве самоврядування : зб. наук. пр. - Дніпро : ДРІДУ НАДУ, 2010. - Вип. 4(7). - С. 74-82.

8. Рубан А. Ефективність виборчих технологій в Україні. Політичний менеджмент. 2011. - № 1. - C. 103-111.

\section{References:}

1. Poychenko, A. (1996). Polityka: teoriya i tekhnolohiyi diyal'nosti [Politics: theory and technology]. Kyiv [in Ukrainian].

2. Vydrin, D. (2001). Polityka: istoriya, tekhnolohiya, ekzystentsiya [Politics: history, technology, existence]. Kyyiv : Lybid' [in Ukrainian].

3. Kutsenko, Y.E. (2013). «Vyborchi tekhnolohiyi» yak naukova katehoriya: sutnist' i klasyfikatsiyi [«Electoral technologies» as a scientific category: essence and classifications]. Naukovi zapysky I Instytutu politychnykh i etnonatsional'nykh doslidzhen' im. I.F. Kurasa NAN Ukrayiny [Scientific notes of the First Institute of Political and Ethnonational Studies. I.F. Kuras NAS of Ukraine] (Vol. 1 / 63), (pp. 387-403) [in Ukrainian].

4. Nal'otov, A. (2007). Vyborchi tekhnolohiyi yak chynnyk vplyvu na masovu svidomist'. Politychnyy menedzhment [Electoral technologies as a factor influencing the mass consciousness. Political management] (Vol. 5), (pp. 126-137) [in Ukrainian].

5. Shveda, Y., Lesechko, I. (2010). Destruktyvni vyborchi tekhnolohiyi v ukrayins'kiy vyborchiy praktytsi [Destructive election technologies in Ukrainian election practice]. Naukovyy visnyk Uzhhorods'koho universytetu. Seriya: Politolohiya, Sotsiolohiya, Filosofiya [Scientific Bulletin of Uzhhorod University. Series: Political Science, Sociology, Philosophy] (Vol. 15), (pp. 117-120) [in Ukrainian].

6. Il'nyts'kyy, M. (2018). Vyborchi tekhnolohiyi yak forma pravorealizatsiyi [Electoral technologies as a form of law enforcement]. Natsional'nyy yurydychnyy zhurnal: teoriya i praktyka [National Legal Journal: Theory and Practice] (June), (pp. 21-24) [in Ukrainian].

7. Blinov, Y.E. (2010). Protydiya vykorystannyu nelehitymnykh politychnykh tekhnolohiy: ukrayins'kyy i mizhnarodnyy dosvid [Countering the use of illegitimate political technologies: Ukrainian and international experience]. Derzhavne upravlinnya ta mistseve samovryaduvannya [Public administration and local self-government: coll]. Dnipro : DRIDU NADU (Vol. 4 / 7), (pp. 74-82) [in Ukrainian].

8. Ruban, A. (2011). Efektyvnist' vyborchykh tekhnolohiy v Ukrayini [The effectiveness of electoral technologies in Ukraine]. Politychnyy menedzhment [Political management]. (Vol. 1), (pp. 103-111) [in Ukrainian]. 